\title{
GLL
}

Geomatics, Landmanagement and Landscape No. $4 \cdot 2019,51-58$

\section{PUBLIC REAL ESTATE MANAGEMENT INDEX - A CASE STUDY OF EUROPEAN STATES}

\section{Marta Gross}

\section{Summary}

Public property management should be effective, considering the limited resources that public economies have at their disposal.

The aim of the present article is to develop an integrated indicator - Public Real Estate Management Index (PREMI) - for the analysed countries, and to indicate their relative scores in the ranking, and particularly to indicate their position within Poland's classification system. The results published by various international organizations were used in order to determine the total PREMI scores.

\section{Keywords}

Public Real Estate Management Index • real estate management • public sector

\section{Introduction}

Public property management should be conducted effectively and efficiently, considering the limited resources that public entities have at their disposal.

The aim of the present article is to develop an integrated indicator - Public Real Estate Management Index (PREMI) - for the analysed countries, and to indicate their relative scores in the ranking, and particularly to indicate their position within Poland's classification system. Selected public real estate management systems in 10 European countries were adopted as the research area. Post-socialist states such as Poland, the Czech Republic, Slovakia, Lithuania, Latvia, Estonia, Slovenia were selected alongside Scandinavian countries - Finland, Norway, and Sweden.

\section{Material and methods}

Subsequent stages of the research were presented below (Fig. 1).

Having defined the studied area, the indicators characterizing public real estate management systems were selected. 19 indicators published by various international organizations were used. 


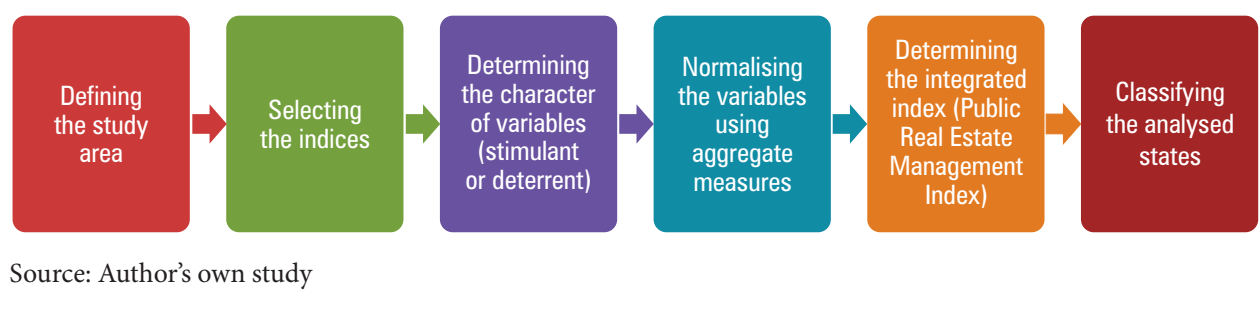

Fig. 1. Stages of the research

One of the indicators used was Government Efficiency (W1), one of the indicators from the Sustainable Governance Indicators 2018 (SGI) group, published by Bertelsmann Stiftung. The score of this index ranges from 1 to 10. In the case of a stimulant variable, the higher the value, the greater the sustainability; while in the case of a deterrent variable, the opposite is true [Schraad-Tischler and Seelkopf 2018].

The next analysed indicator was Resource Efficiency (W2), one of the Transformation Index BTI 2018 indicators, also published by Bertelsmann Stiftung [Donner et al. 2018]. Like the previous indicator, its score ranges from 1 to 10. It is part of the Governance Index. According to Donner et al. [2018], W2 means that the government makes optimal use of the available resources and that real estate management is conducted in an efficient manner. There exist procedures and entities, which are responsible for public administration reform. In addition, there is decentralization of powers (delegating legal and financial autonomy to local selfgovernment units).

The research also uses indicators created by the World Economic Forum (2018):

a. Global Competitiveness Index 4.02018 edition: in this work, we apply the rank of the given state (rank - W3) as well as the score (score - W4) that falls in the range of 1 to 100 ;

b. Budget transparency (W5): from 0 (low transparency) to 100 (high transparency); it determines the range of published information on the budget and spending of the public entity;

c. Efficiency of legal framework in challenging regulations (W6): from 1 (extremely difficult) to 7 (extremely easy); facility of challenging the government's activities by private entities via the legal system;

d. E-Participation Index (W7): in the range of 0-1 (best); used to evaluate the application of online services in order to facilitate making the information available to the citizens by the government agencies;

e. Future orientation of government (W8): in the range of 1-7 (best); this concerns stable government policy, adaptation to legal regulations, effective approach to changes in the environment, for instance changes linked to the latest technologies;

f. Incidence of corruption (W9): from 0 (highly corrupt) to 100 (very clean); it determines the level of corruption in the public sector; 
g. Property rights (W10): in the range of 1-7 (best); determines the degree of protection of property rights;

h. Quality of land administration (W11): in the range of 0-30 (best); this assesses the quality of the land administration system - the developed infrastructure, transparency of information, resolution of conflicts and disputes pertaining to real estate property, equal access to property rights;

i. Shareholder governance (W12): 0-10 (best); this is used to assess the degree of good governance;

j. Reliance on professional management (W13): 1-7 (best); determines who are the persons in the managerial positions in state companies, with the score from 1 (friends and relatives) to 7 (professional real estate property managers).

Furthermore, this study applies the measure showing how the corruption is perceived in the given country (Corruption Perceptions Index 2018), which is published by Transparency International (2018). We have applied the score (W14) as well as the rank of the given country (W15).

Our study also references the following Kaufmann and Kraay's indices (2019), published on the World Bank website:

a. Control of Corruption (W16): -2.5 - high level of corruption, 2.5 - no corruption;

b. Government Effectiveness (W17): -2.5 - low effectiveness, 2.5 - high effectiveness;

c. Regulatory Quality (W18): -2.5 - low quality, 2.5 - high quality; signifies the government's capacity to formulate and implement the correct policy and legal regulations;

d. Rule of Law (W19): -2.5 - unclear regulations, 2.5 - clearly defined regulations.

Due to the fact that the represented features were described on various scales, in order to determine the synthetic index (i.e. the Public Real Estate Management Index), all features were normalised on homogeneous scales using aggregate measures. The first step was to determine the nature of the variables. Among the 19 variables, 2 are deterrents (Global Competitiveness Index 4.02018 edition - rank, and CORRUPTION PERCEPTIONS INDEX 2018 - rank). They were determined according to the following formula:

$$
x^{\prime}{ }_{i j}=\frac{\max \left\{x_{i j}\right\}-x_{i j}}{\max \left\{x_{i j}\right\}-\min \left\{x_{i j}\right\}}
$$

Conversely, all the other variables are stimulants, and these were determined according to the following formula:

where:

$$
x^{\prime}{ }_{i j}=\frac{x_{i j}-\min \left\{x_{i j}\right\}}{\max \left\{x_{i j}\right\}-\min \left\{x_{i j}\right\}}
$$

$x_{i j}^{\prime} \quad-\quad$ variable after normalising,

$x_{i j} \quad-\quad$ variable before normalising,

$\min \left\{x_{i j}\right\}-$ minimum value of the variable in the given set,

$\max \left\{x_{i j}\right\}-$ maximum value of the variable in the given set. 
In the case of deterrent variables, the higher the value of the variable, the lower the rank. For stimulant variables, the higher the value the better, that is, the given state is ranked higher.

The integrated index (Public Real Estate Management Index - PREMI) was determined according to the following formula:

$$
\operatorname{PREMI}_{i}=\frac{100}{m} \sum_{j=1}^{m} x_{i j}^{\prime}
$$

where:

PREMI $_{i}$ - Public Real Estate Management Index of the $i$-th state,

$m \quad-$ number of features taken into account,

$x_{i j}^{\prime} \quad-$ variable after normalising.

The value of the index ranges from 0 (weak) to 100 (very good real estate property management).

The last stage of the study was to classify the analysed states - that is to place them in the order of ranking according to the Public Real Estate Management Index for respective states.

\section{Results and discussion}

Table 1 lists the values of the variables adopted for the analysis, before normalising.

Table 1. Characteristics adopted for the analysis, before normalising

\begin{tabular}{|c|c|c|c|c|c|c|c|c|c|c|}
\hline Index & $\begin{array}{c}\text { Czech } \\
\text { Rep. }\end{array}$ & Estonia & Finland & Latvia & Lithuania & Norway & Poland & $\begin{array}{c}\text { Slovak } \\
\text { Rep. }\end{array}$ & Slovenia & Sweden \\
\hline W1 & 5 & 4 & 8 & 9 & 7 & 8 & 7 & 6 & 6 & 9 \\
\hline W2 & 8 & 8.7 & $0^{*}$ & 7 & 8.3 & $0^{*}$ & 7.7 & 7.7 & 8 & $0^{*}$ \\
\hline W3 & 71.2 & 70.8 & 80.3 & 66.2 & 67.1 & 78.2 & 68.2 & 66.8 & 69.6 & 81.7 \\
\hline W4 & 29 & 32 & 11 & 42 & 40 & 16 & 37 & 41 & 35 & 9 \\
\hline W5 & 50 & 69.2 & 73.1 & 50 & 73.1 & 76.9 & 61.5 & 65.4 & 76.9 & 73.1 \\
\hline W6 & 2.9 & 4 & 5.6 & 2.8 & 2.9 & 4.4 & 2.4 & 2.4 & 2.7 & 4.7 \\
\hline W7 & 0.62 & 0.91 & 1 & 0.69 & 0.80 & 0.98 & 0.89 & 0.81 & 0.81 & 0.94 \\
\hline W8 & 3.2 & 4.1 & 5.1 & 3.1 & 3.5 & 4.8 & 3.1 & 3.1 & 3.5 & 4.8 \\
\hline W9 & 57 & 71 & 85 & 58 & 59 & 85 & 60 & 50 & 61 & 84 \\
\hline W10 & 4.7 & 5.4 & 6.6 & 4.4 & 4.5 & 5.8 & 3.9 & 4.4 & 4.5 & 5.7 \\
\hline W11 & 25 & 27.5 & 26.5 & 22 & 28.5 & 20 & 19.5 & 26.5 & 23.5 & 27.5 \\
\hline W12 & 6 & 5.7 & 5.7 & 6.7 & 6.7 & 8.3 & 6.3 & 6 & 6.7 & 7.3 \\
\hline W13 & 5.4 & 5.2 & 6.2 & 4.5 & 4.8 & 5.6 & 4.1 & 4.5 & 4.3 & 5.9 \\
\hline W14 & 59 & 73 & 85 & 58 & 59 & 84 & 60 & 50 & 60 & 85 \\
\hline
\end{tabular}




\begin{tabular}{|c|c|c|c|c|c|c|c|c|c|c|}
\hline W15 & 38 & 18 & 3 & 41 & 38 & 7 & 36 & 57 & 36 & 3 \\
\hline W16 & 0.6 & 1.2 & 2.2 & 0.5 & 0.6 & 2.2 & 0.7 & 0.2 & 0.8 & 2.1 \\
\hline W17 & 1.0 & 1.1 & 1.9 & 0.9 & 1.0 & 2.0 & 0.6 & 0.8 & 1.2 & 1.8 \\
\hline W18 & 1.2 & 1.6 & 1.8 & 1.2 & 1.2 & 1.8 & 0.9 & 0.8 & 0.6 & 1.8 \\
\hline W19 & 1.1 & 1.3 & 2.0 & 0.9 & 1.0 & 2.0 & 0.5 & 0.6 & 1.0 & 1.9 \\
\hline
\end{tabular}

* Due to the lack of data, the value of 0 was adopted for further analysis

Source: Author's own study

Table 2 summarizes the variables ultimately adopted for analysis after normalising through aggregate measures. The values of individual indicators fall within the range of 0-1.

Table 2. Characteristics adopted for the analysis, after normalising

\begin{tabular}{|c|c|c|c|c|c|c|c|c|c|c|}
\hline Index & $\begin{array}{l}\text { Czech } \\
\text { Rep. }\end{array}$ & Estonia & Finland & Latvia & Lithuania & Norway & Poland & $\begin{array}{c}\text { Slovak } \\
\text { Rep. }\end{array}$ & Slovenia & Sweden \\
\hline W1 & 0.2 & 0.0 & 0.8 & 1.0 & 0.6 & 0.8 & 0.6 & 0.4 & 0.4 & 1.0 \\
\hline $\mathrm{W} 2$ & 0.9 & 1.0 & 0.0 & 0.8 & 1.0 & 0.0 & 0.9 & 0.9 & 0.9 & 0.0 \\
\hline W3 & 0.3 & 0.3 & 0.9 & 0.0 & 0.1 & 0.8 & 0.1 & 0.0 & 0.2 & 1.0 \\
\hline W4 & 0.4 & 0.3 & 0.9 & 0.0 & 0.1 & 0.8 & 0.2 & 0.0 & 0.2 & 1.0 \\
\hline W5 & 0.0 & 0.7 & 0.9 & 0.0 & 0.9 & 1.0 & 0.4 & 0.6 & 1.0 & 0.9 \\
\hline W6 & 0.2 & 0.5 & 1.0 & 0.1 & 0.2 & 0.6 & 0.0 & 0.0 & 0.1 & 0.7 \\
\hline W7 & 0.0 & 0.8 & 1.0 & 0.2 & 0.5 & 0.9 & 0.7 & 0.5 & 0.5 & 0.8 \\
\hline W8 & 0.1 & 0.5 & 1.0 & 0.0 & 0.2 & 0.9 & 0.0 & 0.0 & 0.2 & 0.9 \\
\hline W9 & 0.2 & 0.6 & 1.0 & 0.2 & 0.3 & 1.0 & 0.3 & 0.0 & 0.3 & 1.0 \\
\hline W10 & 0.3 & 0.6 & 1.0 & 0.2 & 0.2 & 0.7 & 0.0 & 0.2 & 0.2 & 0.7 \\
\hline W11 & 0.6 & 0.9 & 0.8 & 0.3 & 1.0 & 0.1 & 0.0 & 0.8 & 0.4 & 0.9 \\
\hline W12 & 0.1 & 0.0 & 0.0 & 0.4 & 0.4 & 1.0 & 0.2 & 0.1 & 0.4 & 0.6 \\
\hline W13 & 0.6 & 0.5 & 1.0 & 0.2 & 0.3 & 0.7 & 0.0 & 0.2 & 0.1 & 0.9 \\
\hline W14 & 0.3 & 0.7 & 1.0 & 0.2 & 0.3 & 1.0 & 0.3 & 0.0 & 0.3 & 1.0 \\
\hline W15 & 0.4 & 0.7 & 1.0 & 0.3 & 0.4 & 0.9 & 0.4 & 0.0 & 0.4 & 1.0 \\
\hline W16 & 0.2 & 0.5 & 1.0 & 0.2 & 0.2 & 1.0 & 0.2 & 0.0 & 0.3 & 1.0 \\
\hline W17 & 0.3 & 0.4 & 1.0 & 0.2 & 0.3 & 1.0 & 0.0 & 0.1 & 0.4 & 0.9 \\
\hline W18 & 0.5 & 0.9 & 1.0 & 0.5 & 0.5 & 1.0 & 0.2 & 0.2 & 0.0 & 1.0 \\
\hline W19 & 0.4 & 0.5 & 1.0 & 0.3 & 0.3 & 1.0 & 0.0 & 0.1 & 0.4 & 0.9 \\
\hline
\end{tabular}

Source: Author's own study 
Subsequently, the integrated indicator $\left(\mathrm{PREMI}_{\mathrm{i}}\right)$ and ranking of the analysed states were determined (Table 3).

Table 3. PREMI - ranking of the analysed states and values of the index

\begin{tabular}{|l|c|c|c|c|c|c|c|c|c|c|}
\hline Country & Finland & Sweden & Norway & Estonia & Lithuania & Slovenia & $\begin{array}{c}\text { Czech } \\
\text { Rep. }\end{array}$ & Latvia & Poland & $\begin{array}{c}\text { Slovak } \\
\text { Rep. }\end{array}$ \\
\hline Rank & 1 & 2 & 3 & 4 & 5 & 6 & 7 & 8 & 9 & 10 \\
\hline PREMI $_{i}$ & 85.5 & 84.4 & 79.7 & 54.0 & 38.9 & 35.4 & 31.0 & 26.4 & 24.1 & 21.5 \\
\hline
\end{tabular}

Source: Author's own study

The conducted research shows that Finland has the highest PREMI value $=85.5$, and that it is also ranked first among the analysed countries. Sweden had a slightly lower value $(\mathrm{PREMI}=84.4)$. It should be noted that the first 3 positions in the ranking went to the countries located in the Scandinavian Peninsula. Among all the analysed states, these three are the largest economic powers, as evidenced by the highest GDP values at current market prices per person in 2017 (Eurostat 2019). No wonder that PREMI values for these countries were also the highest.

The lowest value was granted to Slovakia $($ PREMI $=21.5)$. Poland was classified $9^{\text {th }}$ with a PREMI score of 24.1, which brings it closer to Latvia, occupying $8^{\text {th }}$ position in the ranking.

The results obtained for individual states can be described as reliable. The obtained results are comparable for example with the values expressed in the 2018 International Property Rights Index - IPRI [Levy-Carciente 2018]. In the case of IPRI, the lowest indicator value was determined for Latvia, which allowed Poland and Slovakia to be ranked higher.

The final stage of the study was to determine the assessment intervals for the developed PREMI indicator (Fig. 2). Five natural intervals specified in the ArcGIS software (very good, good, average, weak, very weak) were applied here. This facilitated the interpretation of the results obtained.

In the present analysis, the Public Real Estate Management Index for Poland was described as very weak. This does not entirely reflect the actual situation, because the low score mainly results from the particular selection of the countries for the analysis. Certainly, the choice of states much less similar to Poland, with a less developed real estate economy, would increase the index score for Poland. 


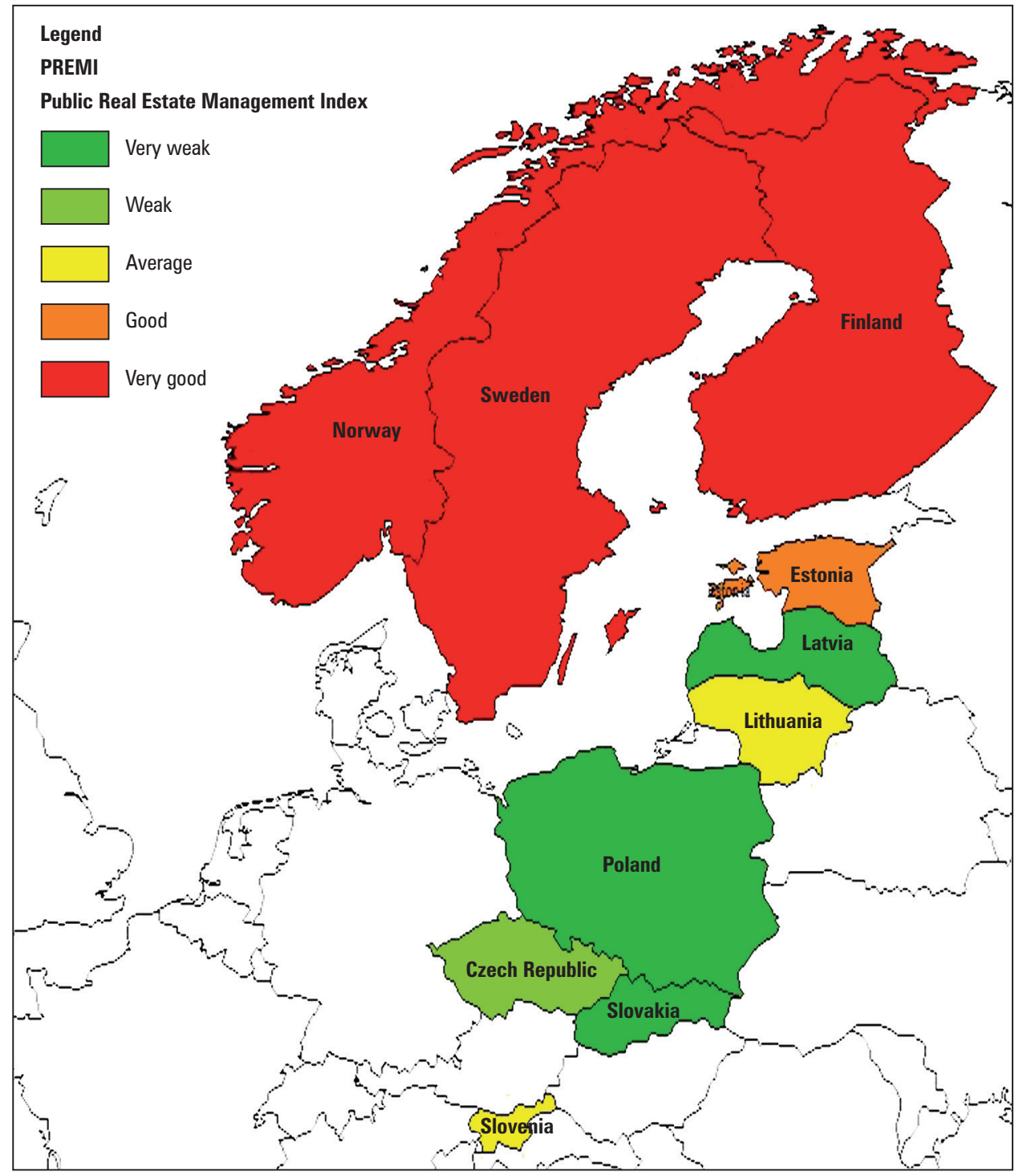

Source: Author's own study

Fig. 2. Public Real Estate Management Index

\section{Conclusions}

The PREMI integrated indicator presented herein is based on 19 international indicators published by various types of organizations. It is helpful when comparing public 
real estate management systems of different countries. The research can be undoubtedly extended to other states, regardless of their geographical location.

However, PREMI has some limitations, primarily in the scope of the indicators analysed. It is changeable over time and therefore requires frequent updates, which unfortunately involves further calculations.

In addition, the value of the PREMI indicator determined for a given country is also dependent on which other countries were adopted for analysis, which to a large extent may sometimes result in obtaining unreliable values. Therefore, the results obtained should also be referred to other sources.

\section{References}

Donner S., Hartmann H., Schwarz R. 2018. BTI 2018 Codebook for Country Assessments. Bertelsmann Stiftung, Gütersloh. https://www.bti-project.org/fileadmin/files/BTI/Downloads/ Zusaetzliche_Downloads/BTI2018_Codebook.pdf [accessed: 24 July 2019].

Eurostat. 2019. GDP at current market prices, 2007 and 2015-2017. https://ec.europa.eu/eurostat/statistics-explained/index.php?title=File:GDP_at_current_market_prices,_2007_ and_2015-2017_FP18.png [accessed: 20 August 2019].

Kaufmann D., Kraay A. 2019. The Worldwide Governance Indicators (WGI) project. https:// info.worldbank.org/governance/wgi/\#home [accessed: 26 July 2019].

Levy-Carciente S. 2018. 2018 International Property Rights Index. Full Report. https:// s3.amazonaws.com/ipri2018/IPRI2018_FullReport2.pdf [accessed: 20 July 2019].

Schraad-Tischler D., Seelkopf L. 2018. Concept and Methodology: Sustainable Governance Indicators 2018. Bertelsmann Stiftung, Gütersloh. https://www.sgi-network.org/2018/Downloads [accessed: 25 July 2019].

Transparency International. 2018. Corruption Perceptions Index 2018. Berlin: Transparency International. www.transparency.org [accessed: 26 July 2019].

World Economic Forum. 2018. The Global Competitiveness Report 2018. Insight Report. Schwab K. (red.). Geneva, World Economic Forum.

Dr inż. Marta Gross

Uniwersytet Warmińsko-Mazurski w Olsztynie

Wydział Geodezji, Inżynierii Przestrzennej i Budownictwa

Instytut Geografii i Gospodarki Nieruchomościami

ul. Prawocheńskiego 15, 10-720 Olsztyn

email: marta.gross@uwm.edu.pl 